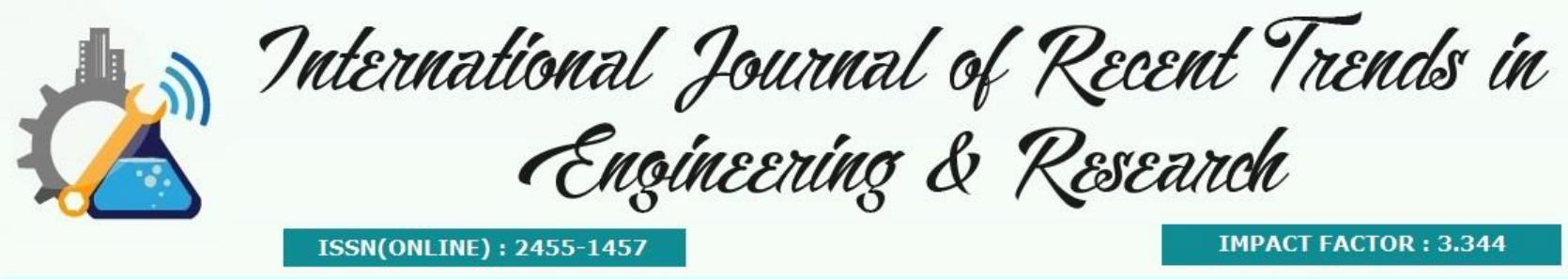

\title{
Decision Support System in Selecting The Appropriate Laptop Using Simple Additive Weighting
}

\author{
Khairul $^{1}$, Manogari Simaremare ${ }^{2}$, Andysah Putera Utama Siahaan ${ }^{3}$ \\ Faculty of Computer Science \\ ${ }^{1,3}$ Universitas Pembangunan Panca Budi \\ ${ }^{2}$ STMIK Triguna Dharma \\ 1,3 Jl. Jend. Gatot Subroto Km. 4,5 Sei Sikambing, 20122, Medan, Sumatera Utara, Indonesia \\ ${ }^{2} J l$. Jenderal Abdul Haris Nasution No. 73F, Medan Johor, 20219, Medan, Sumatera Utara, Indonesia
}

\begin{abstract}
At this time many brands of laptops on the market. They have each specification. Each brand provides different facilities and features. It gives confusion to people who will buy the laptops. It is a difficult choice to make choices according to the wishes and budget. The development of technology can assist people in resolving the problem decision. For example, the use of computer science in providing the best decisions on the issue of election of the laptop. A decision support system for the selection of the laptop will be designed so that the user can determine the choice of laptops accordance with the wishes and abilities. The method used is Simple Additive Weighting. This method was chosen because it can display the best alternative from a number of options. Several criteria will be included for processing. With this method, laptop users can make their choice based on the value of the largest to the smallest value.
\end{abstract}

Keywords - Decision Support System, SAW, Expert System

\section{INTRODUCTION}

A laptop is a mobile intelligent computer system. Because it is portable, it can be used wherever located and help do the job without being tied down to one particular place. Having a laptop has become a necessity and part of the good lifestyle force for education, business, and entertainment. Choosing the right laptop and in accordance with the requirements is not easy. With so many brands on the market and the number of choices offered, is baffled consumers to decide which laptop they think are appropriate to their liking.

Based on these issues, it needs a system that can assist consumers in obtaining a good decision. These results tailored to the needs of consumers who want to achieve. Decision Support System can provide information and alternatives to laptops available in the market. This study uses Simple Additive Weighting. This method can consider the desired results based on parameters as a reference in decision support systems. By applying this approach, it is expected that the result of information can assist consumers in choosing a laptop.

\section{A. Fuzzy Logic}

\section{THEORIES}

Fuzzy logic is a appropriate step to categorize an input space into an output space. A reason to use fuzzy logic is easier to understand these and fuzzy logic if there are incorrect data have a tolerance [1].

In general, the fuzzy logic system has four elements:

* The basic rule that contains the rules derived from the experts.

* A decision-making mechanism in which the expert took the decision to apply the knowledge they have.

* A Fuzzification process that converts the amount into the magnitude fuzzy crisp. 
* A Defuzzification Process which is the reverse of the process that is changing the fuzzification magnitude result of the fuzzy inference engine, being the amount of crisp.

In the implementation of the system, fuzzy has three parts, namely fuzzification, fuzzy inference, and defuzzification. However, the process here is optional defuzzification, i.e., when the conclusion is already meeting or as expected, then no defuzzification process [1][2]. However, if a conclusion has not met the defuzzification process is still being done.

\section{B. Decision Support System}

Decision Support System is a system that can provide problem-solving ability and the ability of alternatives to problems with the condition of both structured and unstructured. This system was created to make decisions in all situations the decision is abstract. This technique aims to provide information, guide, provide predictions and directs the user to the information to make better decisions.

Decision Support System is an implementation decision-making theories that have been introduced by the sciences such as operations research. The difference is that if the first to find a solution to the problems facing the calculations must be done manually; the current computer science has offered the ability to resolve similar issues in a short time.

Decision Support System has five characteristics:
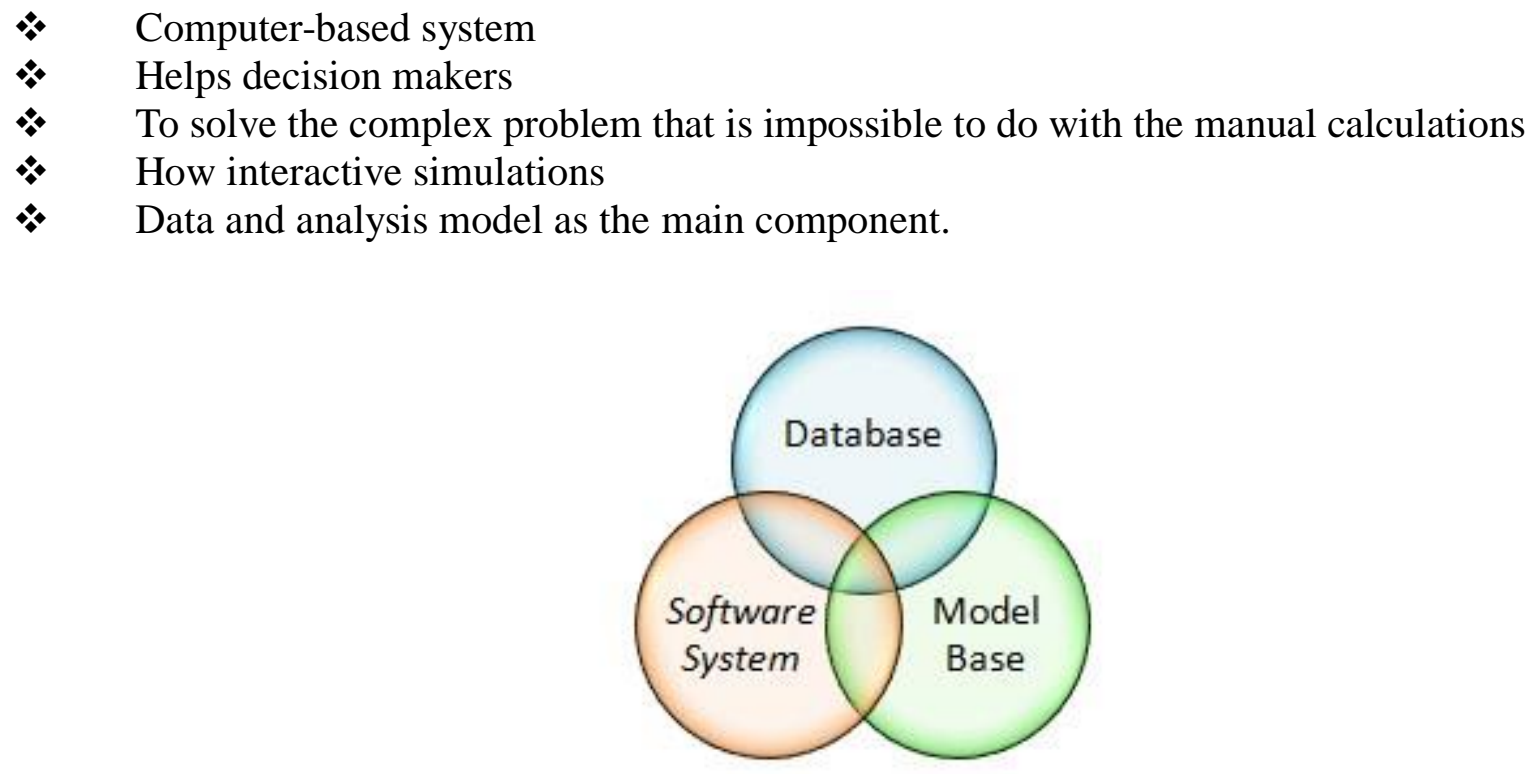

Fig. 1 Decision Support System component

The database system contains a collection of all the data business owned companies or institutions, both derived from daily transactions, as well as basic data. The necessary data relevant to the issues to be solved through simulation [4].

Model Base represents the problem in a quantitative format as the basis of simulations or decisionmaking, including the goal of problems, related components, limitations exist, and other related matters [4].

Software system; both components are henceforth united in the third component is a software system, having previously represented in a model form that is understandable by computers. An example is the use of techniques Relational Database Management System, Object Oriented Database Management System to model data structures. Model Base Management System is used to represent a problem that wants to be solved. Other entities contained in the new DSS product is Dialog Generation and 
Management System. It is a system to allow for interactive dialogue between computers and humans as decision makers [4].

The function of the Decision Support System is to improve the ability of decision makers by providing alternatives decision more or better, so it can help to formulate the problem and the conditions facing. Thus the Decision Support System can save time, effort and cost. So it can be said briefly that the purpose of Decision Support System is to improve the effectiveness and efficiency in decision-making. Suppression of a Decision Support System is on enhancing the effectiveness of decision-making than on efficiency [5].

\section{C. $\quad$ Simple Additive Weighting}

Simple Additive Weighting method is known as a weighted summation method. The SAW process is to seek a weighted sum of rating on the performance of each alternative on all attributes. It needs a matrix normalization. It is to a scale that can be compared with all the ratings of existing alternatives. This method has two attributes, benefits and costs criteria. The fundamental difference of both of these criteria is the selection criterion when making decisions [3][8].

$$
r_{i j=}\left\{\begin{array}{l}
\frac{x_{i j}}{\operatorname{Max}_{i} x_{i j}} \\
\frac{\operatorname{Min}_{i} x_{i j}}{x_{i j}}
\end{array}\right.
$$

$\frac{X i j}{\operatorname{Max}(i) X i j}$ is used if the attribute/criteria is benefit.

$\frac{\operatorname{Min}(i) X i j}{X i j}$ is used if the attribute/criteria is cost.

Where $r_{i j}$ is the normalized performance ratings of alternatives Ai on attributes $C_{j}, i=1,2, \ldots, m$ and $j$ $=1,2, \ldots, \mathrm{n}$. Preference value for each alternative $\left(\mathrm{V}_{\mathbf{i}}\right)$ is given as:

$$
V i=\sum_{j=1}^{n} W j R i j
$$

A larger $\mathrm{V}_{\mathrm{i}}$ value indicates that the alternative $\mathrm{A}_{\mathrm{i}}$ more selected.

\section{A. Criteria}

\section{PROPOSED WORK}

Choosing a laptop is an activity carried out by the prospective buyer. Some of the criteria that will be considered in the determination is as follows:

Price (C1)
$\quad$ Processor (C2)
$\quad$ Scmory / RAM (C3)
$\quad$ Display / VGA (C5)
$\quad$ Harddisk (C6)
$\quad$ Webcam (C8)




\section{Table 1 Price criteria}

\begin{tabular}{|l|c|}
\hline \multicolumn{1}{|c|}{ Price } & Value \\
\hline IDR 1,000,000 - 3,000,000 & 2 \\
\hline IDR 3,000,000 - 5,000,000 & 3 \\
\hline IDR 5,000,000 - 7,000,000 & 4 \\
\hline IDR 7,000,000 - & \\
$15,000,000$ & 5 \\
\hline
\end{tabular}

Table 2 Processor criteria

\begin{tabular}{|l|c|}
\hline \multicolumn{1}{|c|}{ Processor } & Value \\
\hline Atom & 1 \\
\hline Dual Core & 2 \\
\hline Core i3 & 3 \\
\hline Core i5 & 4 \\
\hline Core i7 & 5 \\
\hline
\end{tabular}

Table 3 Memory/RAM criteria

\begin{tabular}{|l|c|}
\hline \multicolumn{1}{|c|}{ Memory/RAM } & Value \\
\hline $1 \mathrm{~GB}$ & 2 \\
\hline $2 \mathrm{~GB}$ & 3 \\
\hline $4 \mathrm{~GB}$ & 4 \\
\hline $8 \mathrm{~GB}$ & 5 \\
\hline
\end{tabular}

Table 4 Screen size criteria

\begin{tabular}{|l|c|}
\hline \multicolumn{1}{|c|}{ Screen Size } & Value \\
\hline 10 inch & 2 \\
\hline 12 inch & 3 \\
\hline 13 inch & 4 \\
\hline 14 inch & 5 \\
\hline
\end{tabular}

Table 5 Display criteria

\begin{tabular}{|c|c|}
\hline \multicolumn{1}{|c|}{ Display } & Value \\
\hline $1 \mathrm{~GB}$ & 2 \\
\hline $2 \mathrm{~GB}$ & 3 \\
\hline $4 \mathrm{~GB}$ & 4 \\
\hline $8 \mathrm{~GB}$ & 5 \\
\hline
\end{tabular}


Table 6 Harddisk criteria

\begin{tabular}{|l|c|}
\hline \multicolumn{1}{|c|}{ Harddisk } & Value \\
\hline$<250 \mathrm{~GB}$ & 1 \\
\hline $320 \mathrm{~GB}$ & 2 \\
\hline $500 \mathrm{~GB}$ & 3 \\
\hline $640 \mathrm{~GB}$ & 4 \\
\hline$>640 \mathrm{~GB}$ & 5 \\
\hline
\end{tabular}

Table 7 Bluetooth criteria

\begin{tabular}{|l|c|}
\hline \multicolumn{1}{|c|}{ Bluetooth } & Value \\
\hline Not Available & 3 \\
\hline Available & 5 \\
\hline
\end{tabular}

Table 8 Webcam criteria

\begin{tabular}{|l|c|}
\hline \multicolumn{1}{|c|}{ Webcam } & Value \\
\hline Not Available & 1 \\
\hline Available & 2 \\
\hline
\end{tabular}

Table 1 through 8 is a list of criteria for each parameter. There will be eight criteria.

\section{EVALUATION}

This section will be tested against the five pieces of data. First of all, this data will be encrypted sequence so that the laptop the best and the worst is not known. Table 9 is a list of laptop data.

Table 9 Laptop Data

\begin{tabular}{|c|c|c|c|c|c|c|c|c|}
\hline Alternative & Price & $\begin{array}{c}\text { Proc } \\
.\end{array}$ & $\begin{array}{c}\text { RA } \\
\text { M }\end{array}$ & $\begin{array}{c}\text { Scree } \\
\text { n }\end{array}$ & $\begin{array}{c}\text { VG } \\
\text { A }\end{array}$ & HDD & $\begin{array}{c}\text { Bluetoo } \\
\text { th }\end{array}$ & $\begin{array}{c}\text { Webca } \\
\text { m }\end{array}$ \\
\hline Lenovo B490-5044 & 4.425 .000 & i3 & $2 \mathrm{~GB}$ & 14 & 2 & $\begin{array}{l}500 \\
\text { GB }\end{array}$ & N/A & A \\
\hline Acer Aspire 4738 & 5.967 .000 & i3 & $2 \mathrm{~GB}$ & 14 & 2 & $\begin{array}{l}500 \\
\text { GB }\end{array}$ & N/A & A \\
\hline Acer Aspire E1 & 7.800 .000 & i5 & $2 \mathrm{~GB}$ & 14 & 2 & $\begin{array}{l}500 \\
\text { GB }\end{array}$ & N/A & A \\
\hline HP Envy & 4.500 .000 & i3 & $2 \mathrm{~GB}$ & 14 & 2 & $\begin{array}{l}500 \\
\text { GB }\end{array}$ & A & A \\
\hline $\begin{array}{l}\text { Sony Vaio SVE11- } \\
135 \mathrm{CV}\end{array}$ & 6.000 .000 & i3 & $2 \mathrm{~GB}$ & 14 & 2 & $\begin{array}{l}320 \\
\text { GB } \\
\end{array}$ & N/A & A \\
\hline
\end{tabular}


Table 10 Weight in criteria

\begin{tabular}{|c|c|c|c|c|c|c|c|c|}
\hline A & C1 & C2 & C3 & C4 & C5 & C6 & C7 & C8 \\
\hline A1 & 3 & 3 & 3 & 5 & 3 & 3 & 3 & 5 \\
\hline A2 & 4 & 3 & 3 & 5 & 3 & 3 & 3 & 5 \\
\hline A3 & 5 & 4 & 3 & 5 & 3 & 3 & 3 & 5 \\
\hline A4 & 3 & 3 & 3 & 5 & 3 & 3 & 5 & 5 \\
\hline A5 & 4 & 3 & 3 & 5 & 3 & 2 & 3 & 5 \\
\hline
\end{tabular}

Table 10 shows the weight of each criteria. The weight is set from 1 to 5 .

$$
W=\left[\begin{array}{llllllll}
4 & 3 & 2 & 5 & 3 & 3 & 3 & 5
\end{array}\right]
$$

$\mathrm{W}$ is the intial weight.

$$
X=\left[\begin{array}{llllllll}
3 & 3 & 3 & 5 & 3 & 3 & 3 & 5 \\
4 & 3 & 3 & 5 & 3 & 3 & 3 & 5 \\
5 & 4 & 3 & 5 & 3 & 3 & 3 & 5 \\
3 & 3 & 3 & 5 & 3 & 3 & 5 & 5 \\
4 & 3 & 3 & 5 & 3 & 2 & 3 & 5
\end{array}\right]
$$

At this stage, the matrix $\mathrm{X}$ will be normalized to the matrix $\mathrm{W}$ and became matrix $\mathrm{R}$. Calculation of matrix $R$ requires the classification criteria into the value of the benefit and cost as shown in Table 11.

Table 11 Criteria Classification

\begin{tabular}{|c|c|c|}
\hline Criteria & Benefit & Cost \\
\hline Price & - & $\checkmark$ \\
\hline Processor & $\checkmark$ & - \\
\hline Memory/RAM & $\checkmark$ & - \\
\hline Screen & $\checkmark$ & - \\
\hline Display/VGA & $\checkmark$ & - \\
\hline Harddisk & $\checkmark$ & - \\
\hline Bluetooth & $\checkmark$ & - \\
\hline Webcam & $\checkmark$ & - \\
\hline
\end{tabular}

$$
R=\left[\begin{array}{cccccccc}
1 & 0.75 & 1 & 1 & 1 & 1 & 0.6 & 1 \\
0.75 & 0.75 & 1 & 1 & 1 & 1 & 0.6 & 1 \\
0.75 & 1 & 1 & 1 & 1 & 1 & 0.6 & 1 \\
1 & 0.75 & 1 & 1 & 1 & 1 & 1 & 1 \\
0.75 & 0.75 & 1 & 1 & 1 & 0.67 & 0.6 & 1
\end{array}\right]
$$

The above matrix $\mathrm{R}$ is the result of normalized matrix. The alternative value is obtained by processing 
the previous formula.

$$
\begin{aligned}
\mathrm{V} 1= & (4 * 1)+(3 * 0.75)+(2 * 1)+(5 * 1)+ \\
& (3 * 1)+(3 * 1)+(3 * 0.6)+(5 * 1) \\
= & 4+2.25+2+5+3+3+1.8+5 \\
= & 26.05 \\
\mathrm{~V} 2= & (4 * 0.75)+(3 * 0.75)+(2 * 1)+(5 * 1)+ \\
& (3 * 1)+(3 * 1)+(3 * 0.6)+(5 * 1) \\
= & 3+2.25+2+5+3+3+1.8+5 \\
= & 25.05 \\
\mathrm{~V} 3= & (4 * 0.6)+(3 * 1)+(2 * 1)+(5 * 1)+ \\
& (3 * 1)+(3 * 1)+(3 * 0.6)+(5 * 1) \\
= & 2.4+3+2+5+3+3+1.8+5 \\
= & 25.2 \\
\mathrm{~V} 4= & (4 * 1)+(3 * 0.75)+(2 * 1)+(5 * 1)+ \\
& (3 * 1)+(3 * 1)+(3 * 1)+(5 * 1) \\
= & 4+2.25+2+5+3+3+3+5 \\
= & 27.25 \\
\mathrm{~V} 5= & (4 * 0.75)+(3 * 0.75)+(2 * 1)+(5 * 1)+ \\
& (3 * 1)+(3 * 0.67)+(3 * 0.6)+(5 * 1) \\
= & 3+2.25+2+5+3+2.01+1.8+5 \\
= & 24.06
\end{aligned}
$$

\section{Table 12 SAW result}

\begin{tabular}{|l|r|}
\hline \multicolumn{1}{|c|}{ Alternative } & Result \\
\hline Lenovo B490-5044 & 26.02 \\
\hline Acer Aspire 4738 & 25.05 \\
\hline Acer Aspire E1 & 25.20 \\
\hline HP Envy & 27.25 \\
\hline $\begin{array}{l}\text { Sony Vaio SVE11- } \\
\text { 135CV }\end{array}$ & 24.06 \\
\hline
\end{tabular}

Table 12 shows the result of the SAW calculation. It can be seen that HP Envy got the first rank while Sony Vaio SVE11-135CV got the last one.

\section{CONCLUSION}

Based on the descriptions of the problems and discussions in the previous chapters, the authors can conclude that the Simple Additive Weighting can be applied in finding the best alternative to the decision to purchase a laptop. Application of the method the computer store is very helpful to provide information to consumers. They can choose a laptop according to their tastes and abilities. With this approach, users can calculate the power of purchasing item. 


\section{REFERENCES}

[1] M. Iswan, Khairul and A. P. U. Siahaan, "Fuzzy Logic Concept in Technology, Society, and Economy Areas in Predicting Smart City," International Journal of Recent Trends in Engineering \& Research, vol. 2, no. 12, 2016.

[2] A. P. U. Siahaan, "Fuzzification of College Adviser Proficiency Based on Specific Knowledge," International Journal of Advanced Research in Computer Science and Software Engineering, vol. 6, no. 7, pp. 164-168, 2016.

[3] D. Pratiwi, J. P. Lestari and D. A. R., "Decision Support System to Majoring High School Student Using Simple Additive Weighting Method," International Journal of Computer Trends and Technology, vol. 10, no. 3, pp. 153-159, 2014.

[4] F. Said, "Konsep Sistem Pendukung Keputusan (SPK)," [Online]. Available: http://fairuzelsaid.com/konsep-sistem-pendukung-keputusan-spk/. [Accessed 2012 2016].

[5] V. Exa, "Pengertian Dan Fungsi Sistem Pendukung Keputusan (SPK)," 2212015 . [Online]. [Accessed 2012 2016].

[6] R. H. Sparague and W. H. J., Decision Support Systems: Putting Theory Into Practice, vol. 11, New Jersey: Prentice Hall, 1993, pp. 2544-2551.

[7] E. Turban and J. E. Aronson, Decision Support Systems and Intelligent Systems. 6th edition, vol. 6, New Jersey: Prentice Hall, 2001, pp. 697-704.

[8] O. S. Widayanti Deni and A. Sasmita, "Analysis and Implementation Fuzzy Multi-Attribute Decision Making SAW Method for Selection of High Achieving Students in Faculty Level," IJCSI International Journal of Computer Science Issues, vol. 10, no. 1, pp. 674-680, 2013. 